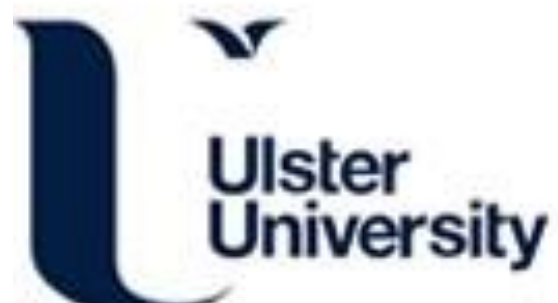

\section{Assessment of Skempton's pore water pressure parameters B and A using a high- capacity tensiometer}

Sanlon, P., Sivakumar, V., Solan, B., Tripathy, S., Mackinnon, P., Donohue, S., \& Ramaiah, B. J. (2021).

Assessment of Skempton's pore water pressure parameters B and A using a high-capacity tensiometer. Géotechnique, 71(2), 110-119. https://doi.org/10.1680/jgeot.18.p.191

Link to publication record in Ulster University Research Portal

\section{Published in:}

Géotechnique

Publication Status:

Published (in print/issue): 28/02/2021

DOI:

10.1680/jgeot.18.p.191

\section{Document Version}

Author Accepted version

\section{General rights}

Copyright for the publications made accessible via Ulster University's Research Portal is retained by the author(s) and / or other copyright owners and it is a condition of accessing these publications that users recognise and abide by the legal requirements associated with these rights.

\section{Take down policy}

The Research Portal is Ulster University's institutional repository that provides access to Ulster's research outputs. Every effort has been made to ensure that content in the Research Portal does not infringe any person's rights, or applicable UK laws. If you discover content in the Research Portal that you believe breaches copyright or violates any law, please contact pure-support@ulster.ac.uk. 


\title{
Assessment of Skempton's pore water pressure parameters $B$ and $A$ using a high-capacity tensiometer
}

\author{
PHILIP SANLON*, VINAYAGAMOOTHY SIVAKUMAR†, BRIAN SOLAN $\$$, SNEHASIS TRIPATHY§, \\ PAULINE MACKINNON $\uparrow$, SHANE DONOHUE $\|$ and BATHALA JANAKI RAMAIAH
}

\begin{abstract}
Saturation of soils is a prerequisite in many laboratory tests involving consolidation, permeability and stress-strain behaviour. The saturation process is usually time consuming, particularly in clay-rich soils, and this can incur substantial cost and potential delays in reporting findings. The saturation of samples is assessed using the well-established Skempton's pore water pressure parameter $B$. In a situation where the soil is fully saturated, the $B$-value is approximately one. It is often the case that fine soil samples extracted from the ground, particularly those from below the water table, remain saturated. However, current testing protocols require evidence to verify a complete saturation prior to subsequent laboratory investigations. This paper reports experimental results exploring the hypothesis that, if the sample is 'perceived' to be saturated, then further saturation procedures may not be necessary to obtain reliable geotechnical parameters. Laboratory investigations were conducted on three different clays (kaolin clay, Belfast clay and Oxford clay) in a testing chamber instrumented with a high-capacity tensiometer. The confining pressures were applied in a ramped fashion under undrained conditions. The response of the tensiometer confirmed that the samples were saturated from the very beginning of the loading process, as implied by the $B$-value being close to one. Further supplementary investigations were carried out to assess the Skempton's pore water pressure parameter $A$ and the stress-strain behaviour of the soils. The combined finding provides further evidence to suggest that the saturation process as suggested in standards may not be necessary for fine-grained soils to establish reliable geotechnical design parameters.
\end{abstract}

KEYWORDS: clays; laboratory tests; mineralogy; pore pressures; sampling; suction

\section{INTRODUCTION}

The extraction of soil samples from the ground under 'perfect conditions' (Class 4 sampling) generates negative pore water pressure (Carrubba, 2000; Hight \& Leroueil, 2003: Donohue \& Long, 2009, 2010; Delage et al., 2016). Whether or not the negative pore water pressure makes air get into the voids and causes the sample to become de-saturated (i.e. the degree of saturation $S_{\mathrm{r}}<1$ ) depends on various factors: material type (particle size distribution), stress history, clay mineralogy and soil density (Young et al., 1983; Graham \& Lau, 1988: Doran et al., 2000; Long, 2003; Sivakumar et al., 2009). Lynch et al. (2019) suggested that, for clay-rich soils such as kaolin, the suction (i.e. the negative pore water pressure) required to initiate the desaturation process is greater than $1000 \mathrm{kPa}$, but for other clay-rich soils, for example Belfast clay and Oxford clay, this value may be much higher due to their mineralogical compositions. However, in many cases the suction in a sample recovered from moderate depths (say up to $50 \mathrm{~m}$ below the ground level) is much less than the suction required for the air to enter the void spaces. In such cases,

Manuscript received 31 July 2018; revised manuscript accepted 10 October 2019.

Discussion on this paper is welcomed by the editor.

* Byrne Looby Partners, Belfast, UK.

$\uparrow$ School of Natural and Built Environment, Queen's University Belfast, Belfast, UK.

* Belfast School of Architecture and the Built Environment, Ulster Universty, Newtownabbey, UK.

$\S$ School of Engineering, Cardiff University, Cardiff, UK.

|| School of Civil Engineering, University College Dublin, Dublin, Ireland.

T Department of Civil and Environmental Engineering, Indian Institute of Technology Tirupati, Tirupati, India. although the soil possesses suction, the sample remains saturated. Nevertheless, the current testing standards provide procedures to ensure full saturation of soil samples. The main limitation of the existing procedure is that it does not have provision to measure the negative pore water pressure in the sample before applying any external stresses.

Skempton (1954) proposed a hypothesis for the development of pore water pressure upon external loading using two parameters, namely $B$ and $A$. Since then the hypothesis has been widely accepted among geotechnical engineering practitioners and academics (Clayton et al., 1995; BS EN ISO 17892-9 (BSI, 2018)). The excess pore water pressure in soils during changes in stress regimes can be determined, for axial symmetry stress conditions, using the following equation involving the pore water pressure parameters $B$ and $A$ (Skempton, 1954).

$$
\Delta u=B\left[\Delta \sigma_{3}+A\left(\Delta \sigma_{1}-\Delta \sigma_{3}\right)\right]
$$

where $\Delta u$ is the change in pore water pressure and $\Delta \sigma_{1}$ and $\Delta \sigma_{3}$ are the changes in major and minor principal stresses, respectively. There are two aspects that need attention

(a) the $B$-value which symbolises the degree of saturation of the sample

(b) the $A$-value which symbolises the changes in pore water pressure under shear loading.

$B$-value. The primary purpose of this investigation was to assess the $B$-value of clay-rich soils subjected to the removal of external loading under undrained conditions (symbolising the extraction of samples from the ground under perfect sampling conditions). The removal of overburden stresses during sampling generates negative pore water pressure within the soil. If that negative pore water pressure is sufficient to allow air to enter the pore spaces (e.g. in the case of silt 
and sand), then the saturation process is essential, and that can only be confirmed by assessing the $B$-value. In clay-rich soils such negative pore water pressure should be extremely high for the air to get into the void spaces, but this is not usually the case. This paper therefore reports a vast amount of data to confirm that the samples of clay-rich soils remain saturated even when high external stresses are removed.

$A$-value. If the material is linearly elastic, isotropic and subjected to undrained loading or unloading, $A=1 / 3$. In normally consolidated soils, the $A$-value varies non-linearly with the shear strain. Skempton \& Sowa (1963) applied equation (1) to understand the impact of stress changes during sampling which was considered to be an elastic process. They pointed out that, in general, there is no reason to suppose that $A=1 / 3$ in natural soils which are often anisotropic. Doran et al. (2000) revised the Skempton's pore water pressure parameter $A_{\mathrm{s}}$ by taking account of anisotropy and derived the following relationship

$$
\begin{aligned}
\Delta u & =B\left[\Delta \sigma_{3}+\left(A-J / 3 G^{*}\right)\left(\Delta \sigma_{1}-\Delta \sigma_{3}\right)\right] \text { where } A_{\mathrm{s}} \\
& =1 / 3-J / 3 G^{*}
\end{aligned}
$$

where $J$ is the coupling parameter and $G^{*}$ is the modified shear modulus (Graham \& Houlsby, 1983). For most natural soils the value of $J / 3 G^{*}$ (which is the slope of the undrained stress path in the $p^{\prime}-q$ plane at low strain (Doran et al., 2000)) is negative ( $p^{\prime}=$ mean effective stress and $q=$ deviator stress). This makes the overall pore water pressure parameter $A$ larger than $1 / 3$. This aspect was also investigated in this paper.

\section{EXPERIMENTAL WORK}

Three different soils were tested, namely: kaolin, Belfast and Oxford clays. All these three soils are clay-rich materials and the relevant physical properties are listed in Table 1.

\section{Sampling procedure}

Four different methods were adopted to generate samples.

Sampling method A. Dry kaolin clay was mixed with de-aired water to achieve a water content of $1.5 \times$ liquid limit using a Cope 2000 mixer. This was consolidated onedimensionally to a vertical pressure of $600 \mathrm{kPa}$ or $800 \mathrm{kPa}$ depending upon the testing requirements (Table 2) in a chamber (100 $\mathrm{mm}$ dia. and $300 \mathrm{~mm}$ high). The consolidation of the slurry lasted 3 days. Upon completion, the external loading was removed and the sample was extruded and trimmed to the required height for further testing.

Sampling method $B$. The correct assessment of the $B$-value requires the testing of materials that have known initial suction values to confirm the reliability of the high-capacity tensiometer used in this study. In sampling method A, although the samples were subjected to known vertical

Table 1. Physical properties

\begin{tabular}{l|c|c|c|l}
\hline Soil type & $\begin{array}{c}\text { Liquid } \\
\text { limit: \% }\end{array}$ & $\begin{array}{c}\text { Plastic } \\
\text { limit: \% }\end{array}$ & $\begin{array}{c}\text { Clay } \\
\text { fraction: \% }\end{array}$ & $\begin{array}{l}\text { Main } \\
\text { mineral }\end{array}$ \\
\hline Kaolin clay & 70 & 30 & 90 & Kaolinite \\
Belfast clay & 60 & 26 & 60 & Illite \\
Oxford clay & 71 & 33 & 75 & Illite \\
\hline
\end{tabular}

stresses, the stress conditions within the samples at the end of the consolidation were not isotropic. In addition, the side friction between the consolidation chamber and the clay impacted the distribution of vertical stresses along the sample. It would, therefore, not be possible to judge the expected suction in the sample upon removal of the consolidation pressure. Therefore, the following procedure was adopted for preparing samples with known suctions upon removal of consolidation pressures.

A $150 \mathrm{~mm}$ dia. membrane was sealed against the pedestal of a triaxial cell. A slurry of kaolin or Belfast clay was then carefully filled into the membrane to a height of $300 \mathrm{~mm}$. In order to avoid bulging of the membrane under the weight of the slurry, the membrane was supported with a thin wire mesh. The top of the membrane was then sealed against a top cap. The triaxial cell was assembled and filled with water and the slurry was subjected to the required confining pressures (isotropic stress conditions) listed in Table 2. Drainage of the water was allowed from the base. The consolidation of the samples lasted $\sim 4$ days for the kaolin clay and 21 days for the Belfast clay. Following the consolidation process a small amount of vacuum was applied on the drainage line to remove the water in the porous disc placed at the bottom of the sample. This procedure was carried out to ensure that the sample would not have access to water upon removal of the cell pressure. The sample was then removed from the system and a thin-wall sample tube with an internal diameter of $100 \mathrm{~mm}$ was used to extract a cylindrical sample. Some of the samples have had further treatment under sampling method C.

Sampling method $C$. It was anticipated that the suction in the sample prepared using sampling method B would be equivalent to the magnitude of the applied external confining pressure in the triaxial cell. However, a concern was that the subsequent extraction of samples using a thin-walled sample tube could have generated sample disturbances (Clayton et al., 1995; Lunne et al., 1997; Donohue \& Long, 2009), which might lead to reduced suction and stiffness. Therefore, as a modification to sampling method B, two kaolin clay samples (tests 9 and 10 in Table 2) and a sample of Belfast clay (test 13) were initially prepared using sampling method B. The extracted samples of $100 \mathrm{~mm}$ dia. and known height were then recompressed to the same consolidation pressures (under isotropic stress conditions) applied during initial formation in a standard triaxial cell, with a $100 \mathrm{~mm}$ dia. pedestal. The intention here was to remove the excess pore water pressure that may have been generated during the sampling process. Once again, before removing the consolidation pressure, the porous disc located at the base of the sample was dried by applying a small amount of vacuum. No further trimming was carried out as the sample changed its volume only marginally.

Sampling method D. Natural samples of Oxford and Belfast clays were delivered to the laboratory in sampling tubes. They were extruded from the tubes (103 $\mathrm{mm}$ dia. core) and carefully trimmed to $100 \mathrm{~mm}$ dia. using a standard soil lathe.

\section{Testing chamber}

Figure 1 shows the testing chamber used in the research. The chamber contained a high-capacity tensiometer, located at the pedestal, which was capable of measuring pore water pressure of $-1500 \mathrm{kPa}$ (Lynch et al., 2019). More details on the tensiometer can be found in Lourenço et al. (2007). 

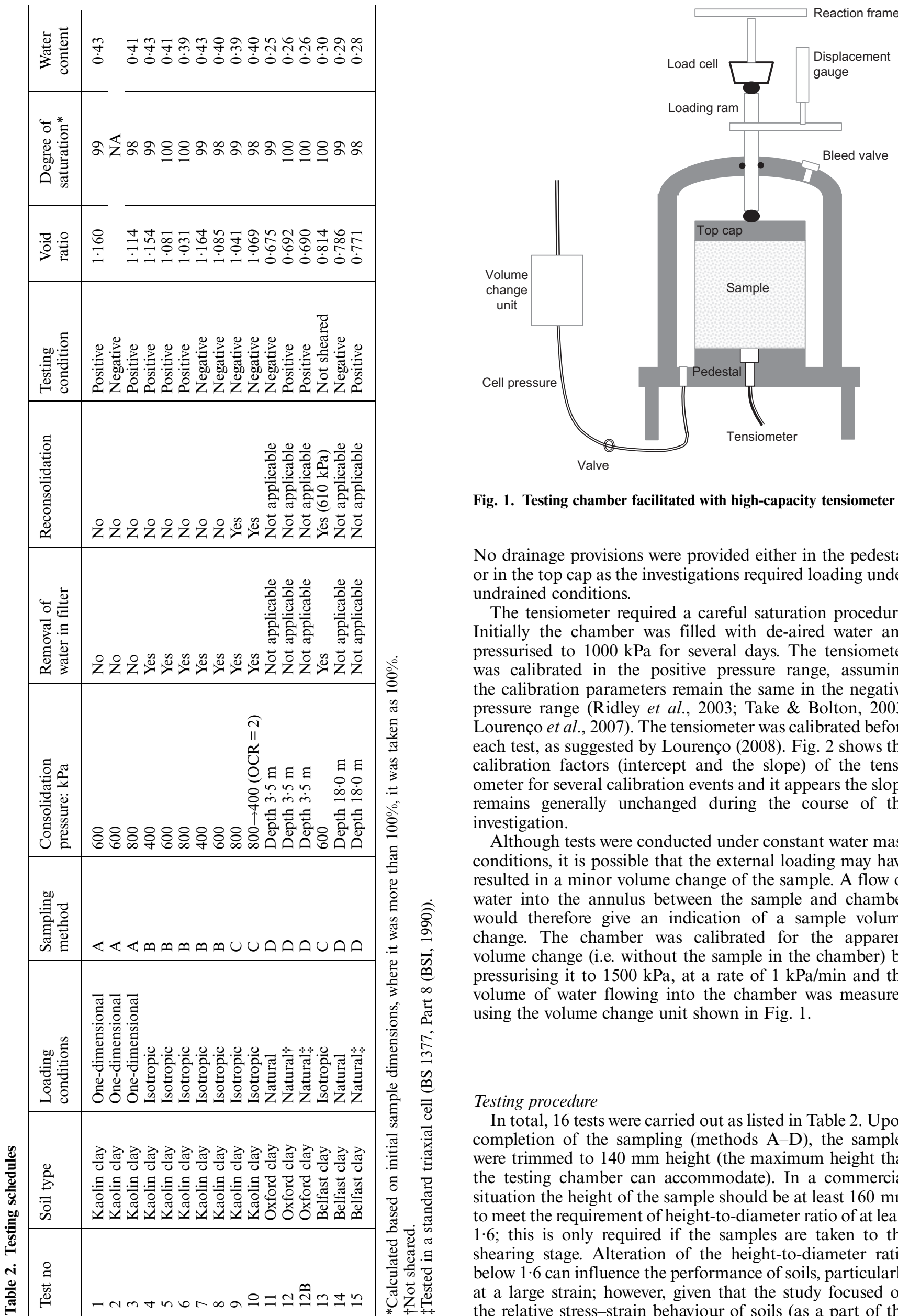

Fig. 1. Testing chamber facilitated with high-capacity tensiometer

No drainage provisions were provided either in the pedestal or in the top cap as the investigations required loading under undrained conditions.

The tensiometer required a careful saturation procedure. Initially the chamber was filled with de-aired water and pressurised to $1000 \mathrm{kPa}$ for several days. The tensiometer was calibrated in the positive pressure range, assuming the calibration parameters remain the same in the negative pressure range (Ridley et al., 2003; Take \& Bolton, 2003; Lourenço et al., 2007). The tensiometer was calibrated before each test, as suggested by Lourenço (2008). Fig. 2 shows the calibration factors (intercept and the slope) of the tensiometer for several calibration events and it appears the slope remains generally unchanged during the course of the investigation.

Although tests were conducted under constant water mass conditions, it is possible that the external loading may have resulted in a minor volume change of the sample. A flow of water into the annulus between the sample and chamber would therefore give an indication of a sample volume change. The chamber was calibrated for the apparent volume change (i.e. without the sample in the chamber) by pressurising it to $1500 \mathrm{kPa}$, at a rate of $1 \mathrm{kPa} / \mathrm{min}$ and the volume of water flowing into the chamber was measured using the volume change unit shown in Fig. 1.

\section{Testing procedure}

In total, 16 tests were carried out as listed in Table 2. Upon completion of the sampling (methods A-D), the samples were trimmed to $140 \mathrm{~mm}$ height (the maximum height that the testing chamber can accommodate). In a commercial situation the height of the sample should be at least $160 \mathrm{~mm}$ to meet the requirement of height-to-diameter ratio of at least $1 \cdot 6$; this is only required if the samples are taken to the shearing stage. Alteration of the height-to-diameter ratio below 1.6 can influence the performance of soils, particularly at a large strain; however, given that the study focused on the relative stress-strain behaviour of soils (as a part of the 


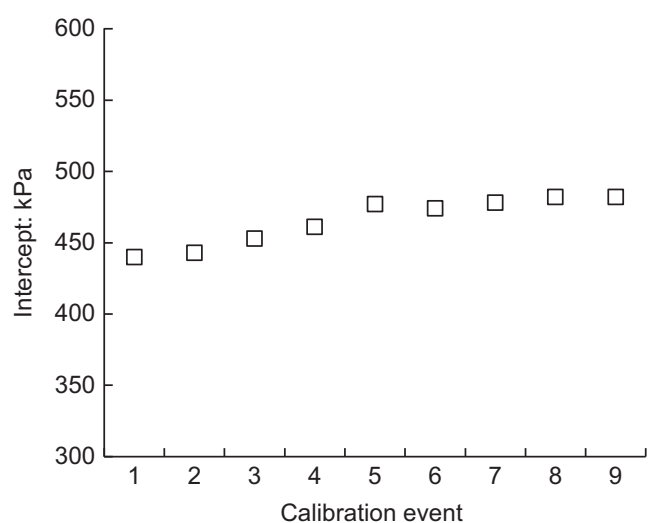

(a)

Fig. 2. Calibration factors for the tensiometer: (a) intercept; (b) slope

$A$-value assessment), this size was deemed acceptable for the current research.

Samples were assembled in the testing chamber and sealed with a rubber membrane. The chamber was filled with de-aired water and pressurised to a nominal cell pressure of $50 \mathrm{kPa}$ and allowed to stabilise for $24 \mathrm{~h}$. Fig. 3 shows the response of the tensiometer. The response time was slightly longer in the case of Belfast and Oxford clays. Both of these clays have considerably lower permeability than kaolin clay. On the following day, the cell pressure was increased to $800 \mathrm{kPa}$ at a rate of $0.8 \mathrm{kPa} / \mathrm{min}$. Upon reaching the target cell pressure and allowing a further $6 \mathrm{~h}$ of stabilisation time (during this resting period there were no significant changes in the pore water pressure), the samples were subjected to shear loading at a rate of $0.08 \mathrm{kPa} / \mathrm{min}$. The test condition in this case is referred to as 'positive loading' (Table 2). In another set of tests, the samples were subjected to shear loading at a cell pressure of $50 \mathrm{kPa}$ without ramping the cell pressure to $800 \mathrm{kPa}$. In these cases, the pore water pressure in the samples remained negative. The testing under this condition is referred to as 'negative loading' (Table 2). Samples of Oxford and Belfast clays were also tested in a standard triaxial cell following the procedure recommended in BS 1377, Part 8 (BSI, 1990).

\section{RESULTS AND DISCUSSION}

\section{Reliability of suction measurements}

To ensure the tensiometer was reading the correct suction values an evaluation was carried out using the data obtained

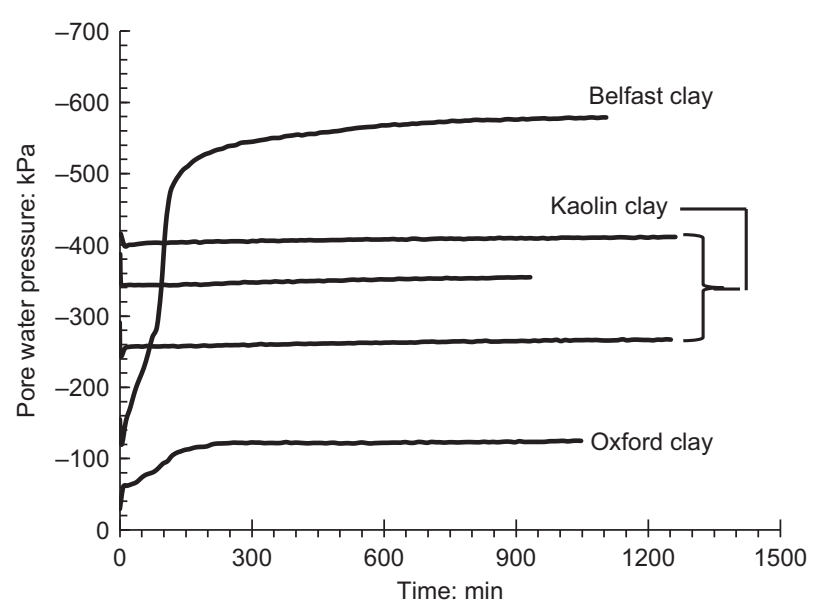

Fig. 3. Response time of the tensiometer to negative pore water pressures in kaolin, Belfast and Oxford clays at $50 \mathrm{kPa}$ of confining pressure

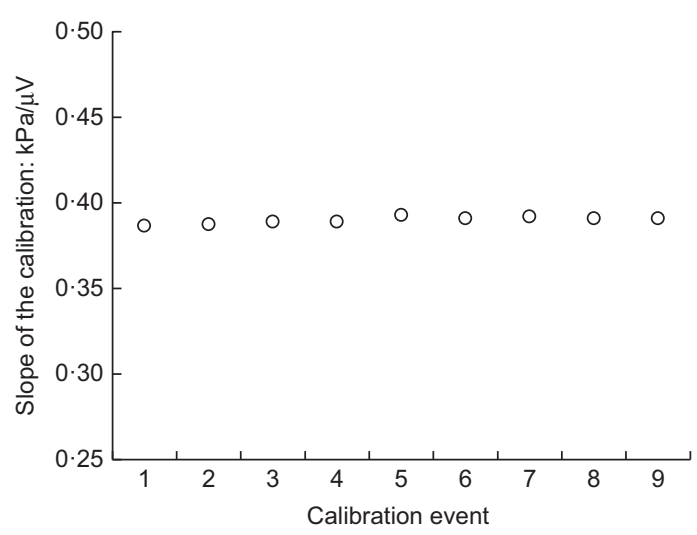

(b)

on a Belfast clay sample (sampling method C, test number 13). Kaolin clay was not considered for this purpose as it tends to undergo significant stress relief upon unloading, which will be further discussed later in the paper. The sample was originally consolidated to $600 \mathrm{kPa}$ of confining pressure in a large triaxial cell $(150 \mathrm{~mm}$ pedestal $)$ and after trimming to the required height it was reconsolidated $610 \mathrm{kPa}$ in a standard triaxial cell $(100 \mathrm{~mm}$ pedestal $)$. Upon the removal of this pressure, the expected negative pore water pressure in the sample was around $-610 \mathrm{kPa}$.

Figure 4 shows the changes in cell pressure $\left(\sigma_{3}\right)$ and pore water pressure $(u)$ in the sample plotted against time during the course of ramping the confining pressure from $50 \mathrm{kPa}$ to $800 \mathrm{kPa}$. During this period, a $0 \cdot 1 \%$ volume change took place and the pore water pressure in the sample increased from $-578 \mathrm{kPa}$ (at a cell pressure of $50 \mathrm{kPa}$ ) to $190 \mathrm{kPa}$. The effective stress in the sample therefore would have been approximately $628 \mathrm{kPa}$, as indicated in Fig. 4. This value was reasonably close to the effective stress in the sample $(617 \mathrm{kPa})$ at the end of the application of cell pressure of $800 \mathrm{kPa}$. There is only an $11 \mathrm{kPa}$ difference between the start and end of the calibration process, which is not significant. These observations gave confidence in the reliability of the tensiometer measurements.

\section{Assessment of B-value}

Figure 5 shows the pore water pressure, plotted against cell pressure, where the cell pressure was ramped from $50 \mathrm{kPa}$ to $800 \mathrm{kPa}$ over a period $48 \mathrm{~h}$ for samples of one-dimensionally compressed kaolin clay (tests 1 and 3), isotropically compressed kaolin clay (tests 4, 5 and 6), isotropically compressed Belfast clay (test 13) and a natural sample of Oxford clay (test 12). The relevant values of initial negative pore water pressure at an external cell pressure of $50 \mathrm{kPa}$ are also included. The reader will notice some small anomalies in the response of the tensiometer in the pressure range between -100 and $100 \mathrm{kPa}$, particularly in the case of Belfast and Oxford clays. The supplier of the tensiometer confirmed that the support systems for the diaphragm containing the strain gauges for the tensiometer were not perfectly matched on either side. This may lead to a situation where the diaphragm responded slightly differently to negative and positive pressures. Overall the tensiometer yielded very useful information for the purpose of this investigation. In all cases, the volumetric strains of the samples when the cell pressures were applied were $<0 \cdot 15 \%$, which is insignificant.

Figure 5 allows a direct evaluation of the $B$-value indicated by the slopes of the lines (solid lines) which highlights how the $B$-values changed with cell pressure. A comparison of the 


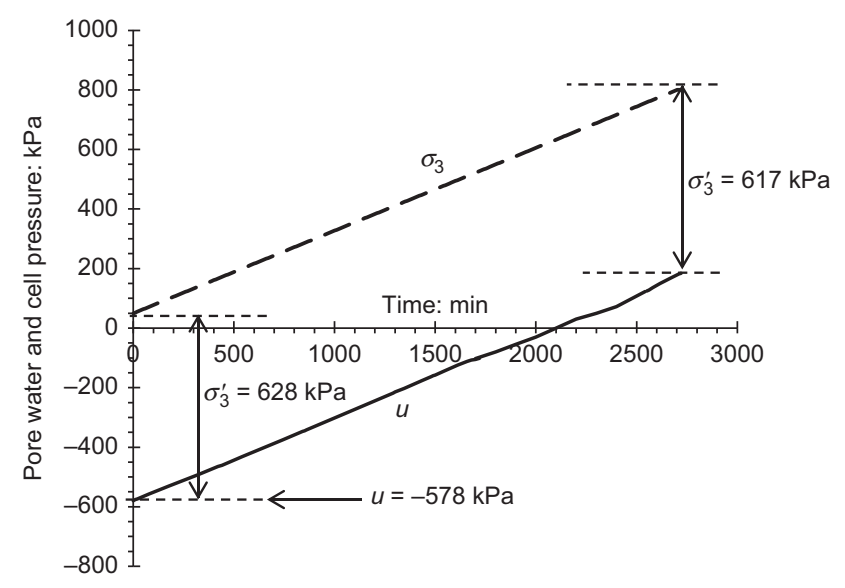

Fig. 4. Decay of negative pore water pressure in Belfast clay during a gradual increase of cell pressure (tensiometer verification, test 13)

theoretical $B$-value lines for saturated soils (shown with dashed lines) with the tested soils confirms that all the samples tested appeared to be saturated from the beginning of the application of the confining pressures. This was indicated by $B$-values $\left(\Delta u / \Delta \sigma_{3}\right)$ of $\sim 1$ (varies between 0.95 and $1 \cdot 0$ ). Interestingly the Belfast clay sample exhibited the same response even with a significant negative pore water pressure of $-578 \mathrm{kPa}$ at the beginning of the application of confining pressure. The slopes of the solid lines seem to suggest that the samples were saturated at the time of extraction, sampling and trimming, therefore prompting a question regarding the need for saturating the samples of clay-rich soils before further testing.

Some additional pieces of information collected from this research allowed the assessment of stress relief (i.e. the expected effective stress in the sample based on the initial consolidation pressure) under unloading conditions. This aspect has been examined by many researchers (Graham \& Lau, 1988). The kaolin clay samples have shown significant stress relief upon unloading under undrained conditions. The samples prepared under one-dimensional consolidation during the initial preparation cannot legitimately be brought into this discussion, as the stress regime, particularly the lateral stresses, is unknown (tests 1, 2 and 3). This could have been one of the possible reasons for significantly lower effective stresses in the samples upon unloading (Table 3). The discussion will therefore focus on the samples prepared using isotropic compression (sampling methods B and C; tests $4-10$ and 13). Table 3 lists the consolidation pressures before sampling, and the effective stresses in the samples, when the specimens were subjected to $50 \mathrm{kPa}$ of confining pressure. The following assessments were made based on the investigations

(a) stress relief in all the kaolin clay samples was significant when sampling method B was adopted (tests 4-8)

(b) stress relief in the sample of Belfast clay was not significant when the sample was prepared using sampling method $\mathrm{C}$ (test 13)

(c) stress relief in the case of the kaolin clay sample prepared using sampling method $\mathrm{C}$ was significant, but less than that observed in the case of samples prepared using sampling method B (tests 9 and 10).

In all of the cases, the water in the filter disc was depleted before the removal of external confining pressures and therefore water influx from the filter disc to the samples cannot be the prime reason for the reduced effective stresses.
Therefore, the possible contributing factors for the reduction in effective stresses under undrained loading (also referred to as stress relief) include: sample disturbances during the extraction process, cavitation of water, particle size distribution and clay mineralogy (Graham \& Lau, 1988).

The influence of sample disturbances (i.e. induced excess pore water pressure) was eliminated by reconsolidating the samples to the same stress history in a standard triaxial cell (sampling method C). This was done in tests 9 and 10 in the case of kaolin clay and test 13 in the case of Belfast clay. Where this procedure was not exercised (tests 4-8) the average stress relief was about $30 \%$. When the reconsolidation process was undertaken, as described in sampling method $\mathrm{C}$, the stress relief was $\sim 10 \%$ in the case of kaolin clay (tests 9 and 10, Table 3). Table 3 demonstrates that the stress relief was not significant in the case of the Belfast clay. On the aspect of cavitation, the negative pore water pressure required for the air to come out of solution in the case of kaolin clay is more than $1000 \mathrm{kPa}$ (Lynch et al., 2019). In addition, information presented in the early part of this paper suggests that the $B$-value was close to 1 and any reasons to postulate any air within the pore spaces are limited. Therefore, the particle size distribution and the mineralogy of the soils tested probably have played a more significant role in relation to the stress relief in kaolin clay.

The kaolin clay used in the present investigation is made of $100 \%$ kaolinite mineral and the kaolinite particles were generally uniform in size. Also, the attractive force is more predominant in the kaolinite-water system. Under external loading, the kaolin particle arrangement tends to be more dispersed (Baille et al., 2014), and in the event of an unloading process, structural rearrangement could take place. In such cases the dispersed structure can become more flocculated, leading to a potential micro-remoulding process. This remoulding resulted in the reduced effective stresses in the samples. In the case of Belfast clay, the clay mineralogy was predominantly illite and therefore the repulsive forces are more predominant (Sridharan \& Jayadeva, 1982). Under external loading, the tendency of the particles to become flocculated is limited, particularly in the presence of silt and sand particles, which are not present in kaolin clay. In the event of removal of external loading, potential structural arrangement is limited, and therefore little or no microremoulding takes place, hence leading to little or no stress relief.

Stress-strain behaviour, stress paths and assessment of pore water pressure parameter A

Figure 6 shows the stress-strain responses of the samples of kaolin clay prepared using sampling methods B and C (tests 4-9). The solid lines indicate the samples tested by bringing the pore water pressure to the positive range. The broken lines indicate when the samples were tested while the pore water pressures were still in the negative range. Both types of loading conditions resulted in similar axial strains at failure $(6-9 \%)$. Given that the loading conditions in the present research were 'stress controlled', it was not be possible to take the samples to a true critical state. The pore water pressure parameter $A(\Delta u / \Delta q)$, varied with axial strain as shown in Fig. 6(b). The value of $A$ gradually increased with axial strain and reached a value approximating to 1 for all the tests, except test 9 (sampling method C). For the latter, the $A$-value was over 1 , which was expected for nearnormally consolidated kaolin clay (Sivakumar et al., 2018). An $A$-value below 1, in the other cases, implies that the samples may have been slightly overconsolidated before the undrained compression. This agrees well with the earlier comment, that samples of kaolin clay prepared using 

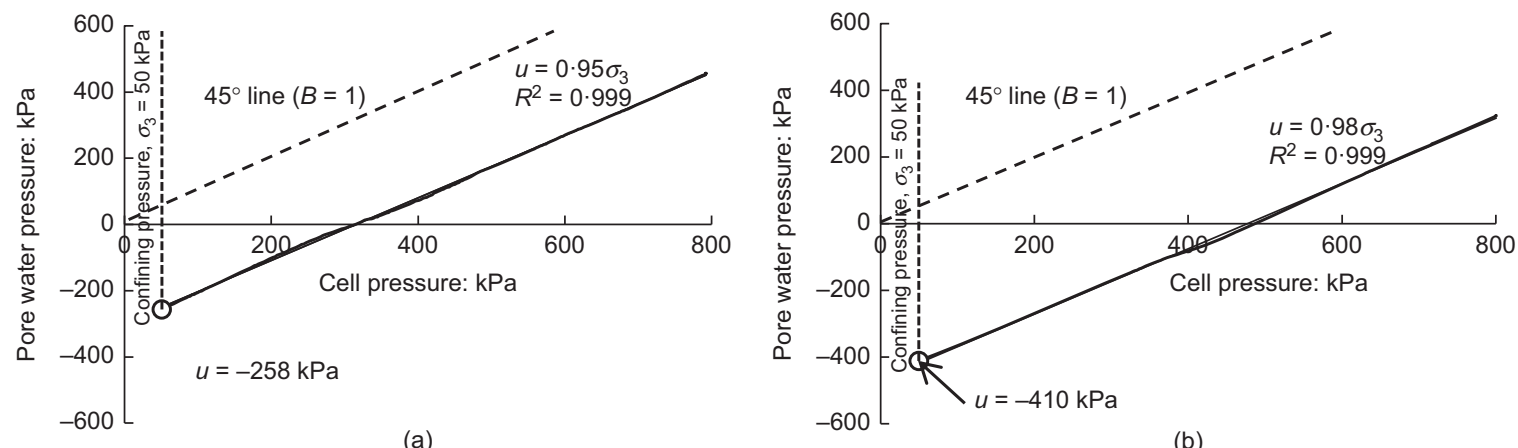

(a)
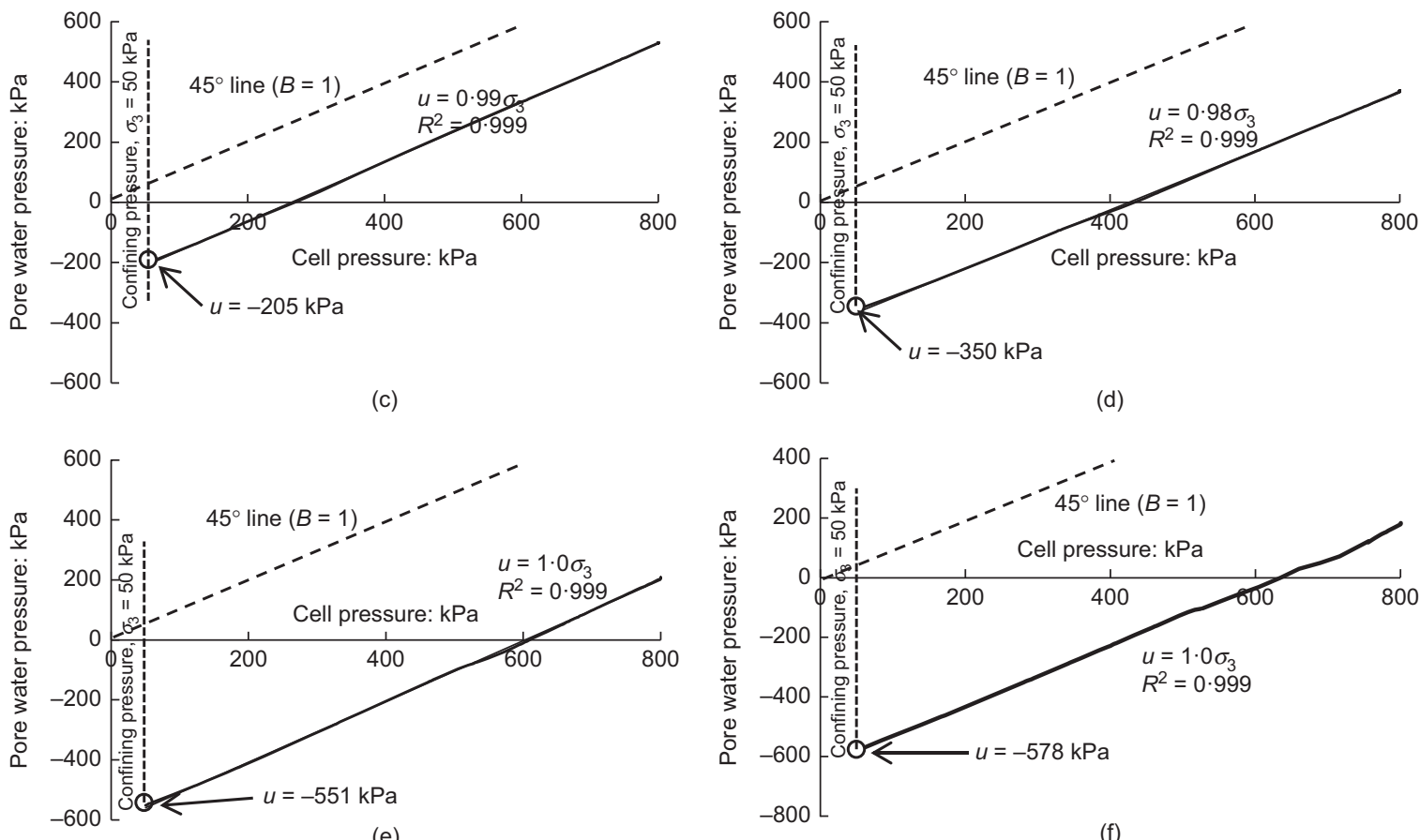

(e)

(f)

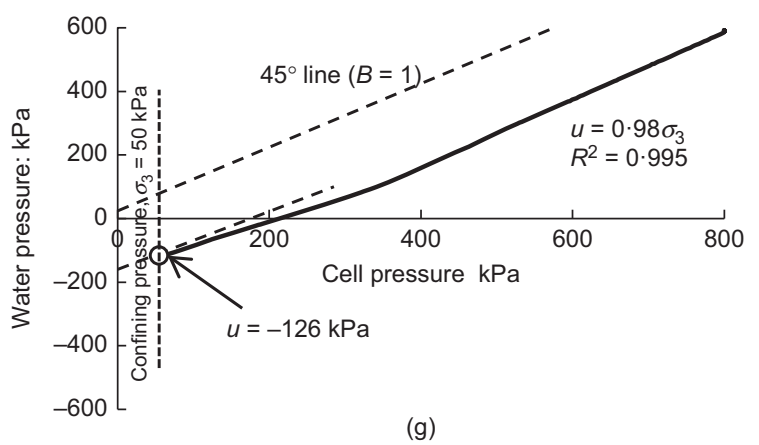

Fig. 5. Assessment of B value of various samples: (a) one-dimensionally consolidated kaolin (600 kPa, test 1); (b) one-dimensionally consolidated kaolin (800 kPa, test 3); (c) isotropically consolidated kaolin (400 kPa, test 4); (d) isotropically consolidated kaolin (600 kPa, test 5 ); (e) isotropically consolidated kaolin $(800 \mathrm{kPa}$, test 6); (f) isotropically consolidated Belfast clay (600 kPa, test 13$)$; (g) natural Oxford clay, test 12

sampling method B have undergone about 30\% stress relief, making them slightly overconsolidated.

Further interesting information was obtained when the responses of the samples during the undrained compression were plotted in terms of $p^{\prime}$ and $q$. To allow a suitable comparison, the stress paths for an overconsolidated sample (test 10, Table 2) and a consolidated undrained compression test carried out by adopting the procedure recommended in BS 1377, Part 8 (BSI, 1990) are shown in Figs 7(a) and 7(b), respectively. The information for the latter was obtained from the authors' database. Fig. 7(a) shows the stress path of the sample tested in test 10 . In this case the overconsolidation ratio was 2 and therefore the sample exhibited classical elastic behaviour at the early stage of compression. The sample inherited isotropic elastic properties during its initial formation, given the previous stress conditions were isotropic. On this basis, the value of the cross-anisotropic parameter $J / 3 G^{*}$ is equal to 0 , implying that the slope of the stress path would be vertical in the $q: p^{\prime}$ plane. Fig. 7(a) shows exactly this, confirming the pore water pressure parameter $A=1 / 3$. Fig. 7(b) shows the stress path for a sample which was consolidated to $800 \mathrm{kPa}$ of effective consolidation pressure prior to undrained shearing. The shape of the stress path is typical of normally consolidated clays, where the stress path 
Table 3. Stress relief in kaolin and Belfast clay

\begin{tabular}{|c|c|c|c|c|c|c|c|}
\hline $\begin{array}{l}\text { Test } \\
\text { no }\end{array}$ & Soil type & Stress conditions & $\begin{array}{l}\text { Sampling } \\
\text { method }\end{array}$ & $\begin{array}{l}\text { Consolidation } \\
\text { pressure: } \mathrm{kPa}\end{array}$ & $\begin{array}{l}\text { Negative pore water pressure } \\
\text { at } 50 \mathrm{kPa} \text { of cell pressure }\end{array}$ & $\begin{array}{l}\text { Effective } \\
\text { stress: } \mathrm{kPa}\end{array}$ & $\begin{array}{l}\text { Stress } \\
\text { relief: } \mathrm{kPa}\end{array}$ \\
\hline 1 & Kaolin clay & One-dimensional & A & 600 & 258 & 308 & Not applicable \\
\hline 2 & Kaolin clay & One-dimensional & A & 600 & 267 & 317 & Not applicable \\
\hline 3 & Kaolin clay & One-dimensional & A & 800 & 410 & 460 & Not applicable \\
\hline 4 & Kaolin clay & Isotropic & B & 400 & 205 & 255 & 145 \\
\hline 5 & Kaolin clay & Isotropic & B & 600 & 356 & 406 & 194 \\
\hline 6 & Kaolin clay & Isotropic & B & 800 & 551 & 601 & 199 \\
\hline 7 & Kaolin clay & Isotropic & B & 400 & 233 & 283 & 117 \\
\hline 8 & Kaolin clay & Isotropic & $\mathrm{B}$ & 600 & 403 & 453 & 147 \\
\hline 9 & Kaolin clay & Isotropic & $\mathrm{C}$ & 800 & 655 & 705 & 99 \\
\hline 10 & Kaolin clay & Isotropic & $\mathrm{C}$ & $\begin{array}{c}800 \rightarrow 400 \\
(\mathrm{OCR}=2)\end{array}$ & 298 & 348 & 52 \\
\hline 13 & Belfast clay & Isotropic & $\mathrm{C}$ & 610 & 578 & 628 & -18 \\
\hline
\end{tabular}

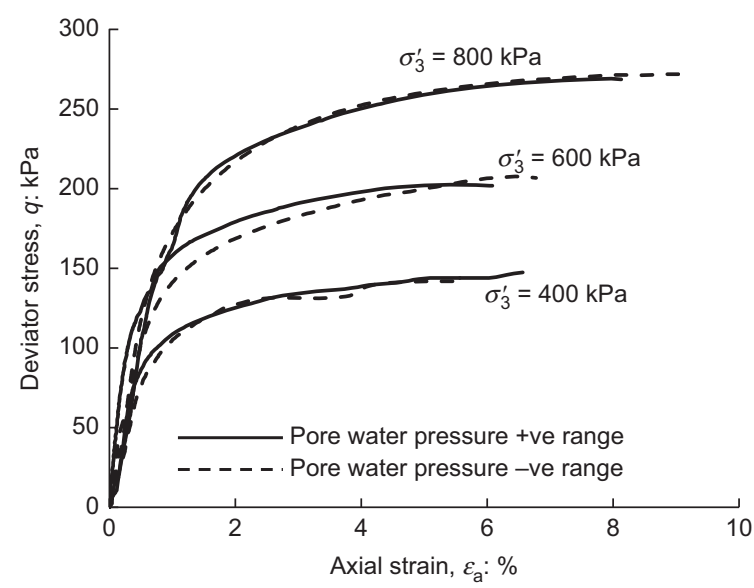

(a)

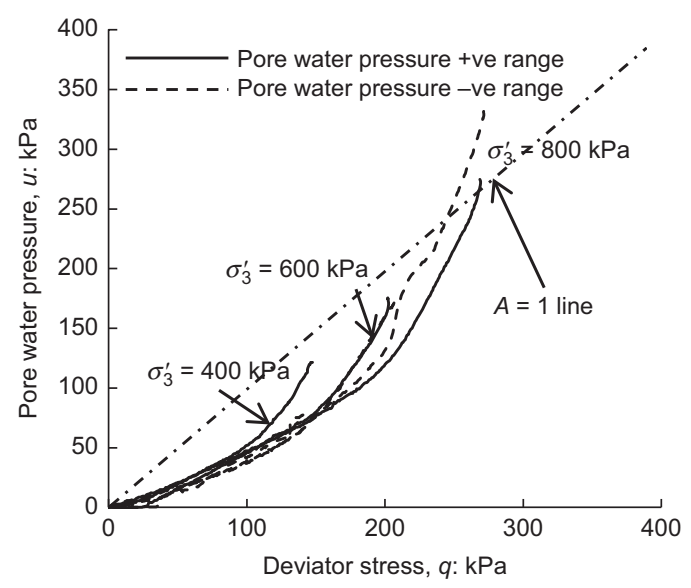

(b)

Fig. 6. Stress-strain and pore water pressure responses of kaolin samples during undrained shearing: (a) deviator stress plotted against axial strain (tests 4-9); (b) change in pore water pressure plotted against change in deviator stress (tests 4-9)

leans toward the $q$ axis from the very beginning of the undrained compressions. These two observations aid the discussion on the stress paths for tests 4-9 (Table 3 ).

The direction of the stress path at the early stage of the shearing (tests 4-9) is approximately vertical irrespective of the loading condition (negative or positive) (see Fig. 7(c)). This indicates that $J / 3 G^{*}$ is equal to 0 , suggesting $A=1 / 3$, and the behaviour of samples was near elastic (i.e. the samples were slightly overconsolidated). This agrees favourably with the earlier comment that stress reliefs in these samples were considerable, mounting up to $30 \%$ in tests $4-8$ and about $10 \%$ in test 9 , which would have made the samples slightly overconsolidated. The stress paths soon lean towards the left and right, for positive and negative loading conditions, respectively, and they approached the nearcritical-state failure condition. The slope of the critical state line, represented by $M$, has a value of approximately 0.7 for positive loading and 0.68 for the negative loading conditions. This equates to an angle of internal friction of $19^{\circ}$. This is considered strong evidence to suggest that the responses of the samples are not significantly affected by the loading conditions (i.e. pore water pressure being positive or negative).

Figure 8 shows the stress paths obtained on samples of Oxford clay, which was in its natural state before testing. One of the samples was tested under negative pore water pressure conditions (test 11) and other sample was tested using the BS 1377, Part 8 (BSI, 1990) procedure (test 12B). The slope of the stress paths at the early stage of shearing was represented by $J / 3 G^{*}$. The cross-anisotropic parameter value was approximately 0.29 under positive loading and 0.27 under negative loading conditions. The agreement between these two values is reasonably good. The slopes of the critical state line in positive and negative loading conditions are 1.44 and $1 \cdot 35$, respectively. The differences are small, contributing to a friction angle difference of just over $1^{\circ}$. For normal design situations this difference in friction angle would not adversely impact the design process. This difference may have been due to possible variations in the natural materials as they were extracted from different sample tubes. In addition, except the sample tested using the BS 1377, Part 8 (BSI, 1990) procedure, the deviator stress was applied using stress control loading and achieving true critical state is not possible. Also note that, as both samples have had significantly different initial effective stresses, consequently they attained different deviator stresses at the critical state. Similar information is echoed in the case of Belfast clay and the relevant information is shown in Fig. 9. The slope of the initial stress path is approximately $0 \cdot 18$ in the case of positive loading (test 15 ) and $0 \cdot 15$ in the case of negative loading (test 14). The slope of the critical state line is 1.04 and 1.0 , respectively, for positive and negative loading, confirming the earlier postulation.

\section{Evaluation}

The information presented in this paper suggests that the $B$-value was 1 for reconstituted and natural samples of 


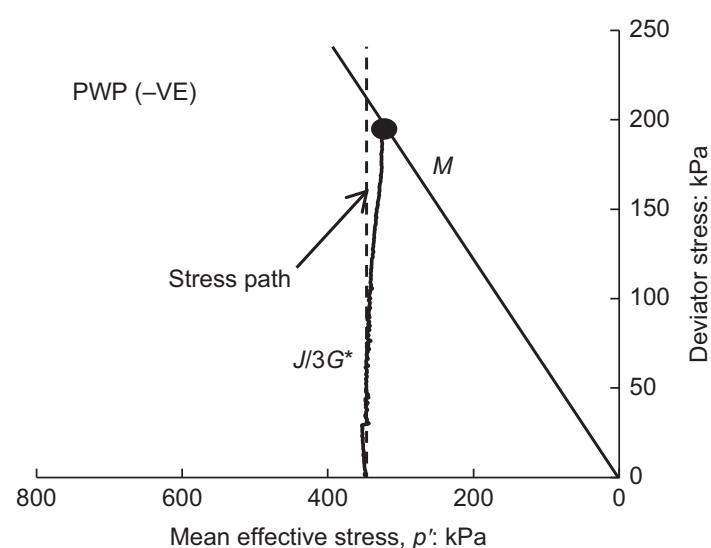

(a)

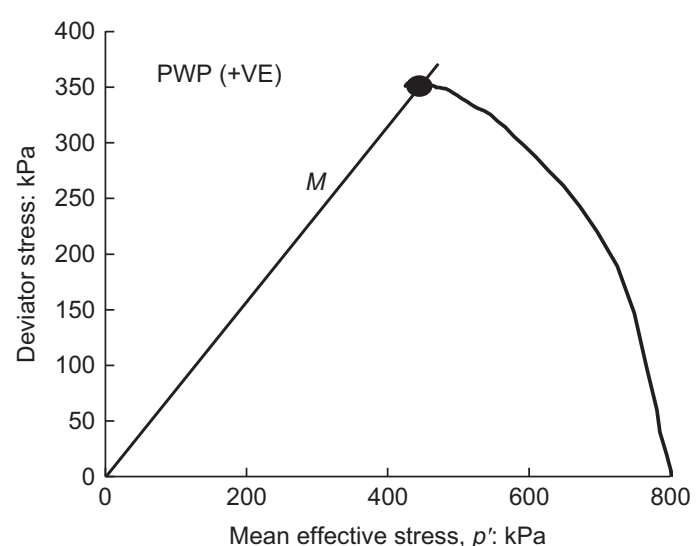

(b)

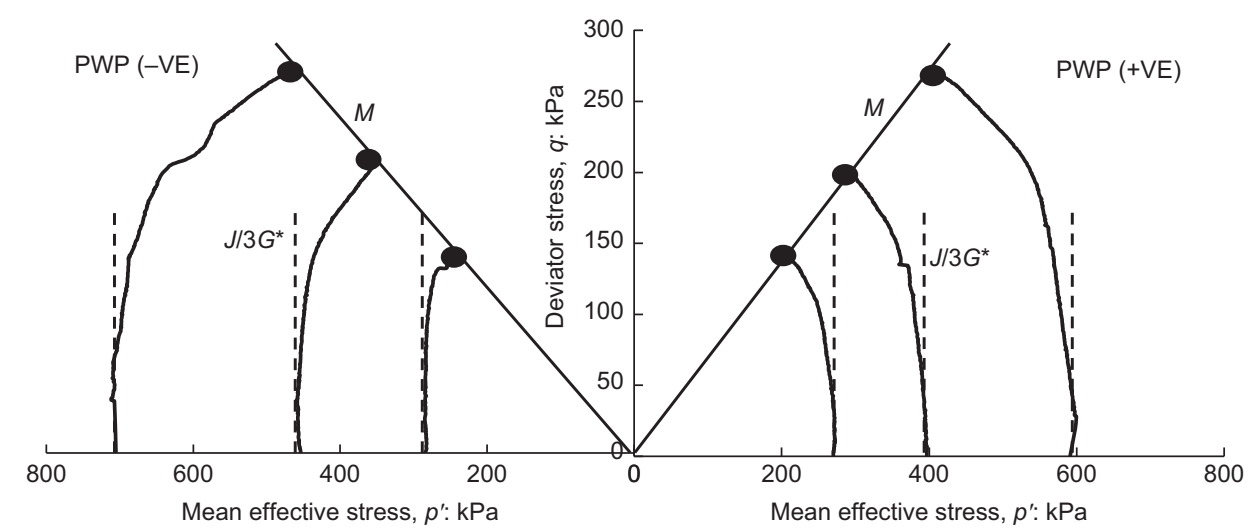

(c)

Fig. 7. Stress paths of normally consolidated and overconsolidated kaolin samples: (a) overconsolidated sample (OCR = 2, test 10); (b) normally consolidated (data from authors' database); (c) stress paths obtained on samples of kaolin with initial pore water pressures (PWPs) in negative $(-\mathrm{VE})$ and positive $(+\mathrm{VE})$ values

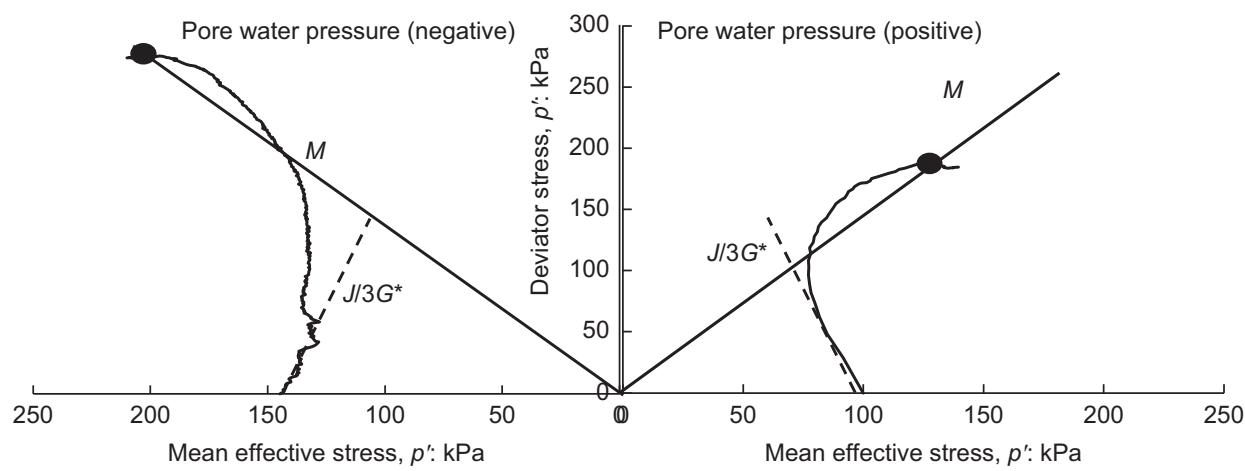

Fig. 8. Stress paths of Oxford clay loaded under undrained conditions (tests 11 and 12B)

predominantly clay-rich materials. According to the BS 1377, Part 8 (BSI, 1990) procedure, a $B$-value approximating to 1 is ensured by increasing the back pore water pressure and cell pressure in steps over a set period of time. In the present investigation, $B$-values $\sim 1$ (after the sampling process) were confirmed by using a high-capacity tensiometer to measure the initial negative pore water pressure in the samples. However, the authors concede the fact that only a few commercial/research laboratories have the provision to use high-capacity tensiometers, therefore implementing the procedure reported herein would be costly. An alternative procedure may be considered, in which the clay-rich samples can be consolidated to the required effective stresses, without the saturation process prior to shearing. Such a procedure was evaluated and proven acceptable for measuring the permeability of compacted clays prepared at the wet of optimum water content (Murray, 2002; Sivakumar \& Anderson, 2015). This research presents evidence to suggest that the strength, anisotropic parameters and the pore water pressure parameter $A$ are unaffected by the alternative testing conditions.

\section{CONCLUSIONS}

The saturation of samples for laboratory investigations is assessed by determining the pore water pressure parameter, $B$. This paper examined whether the saturation process is necessary in clay-rich soils using a chamber equipped with a high-capacity tensiometer. As a part of the investigation, the Skempton's pore water pressure parameter $A$ was also studied. 


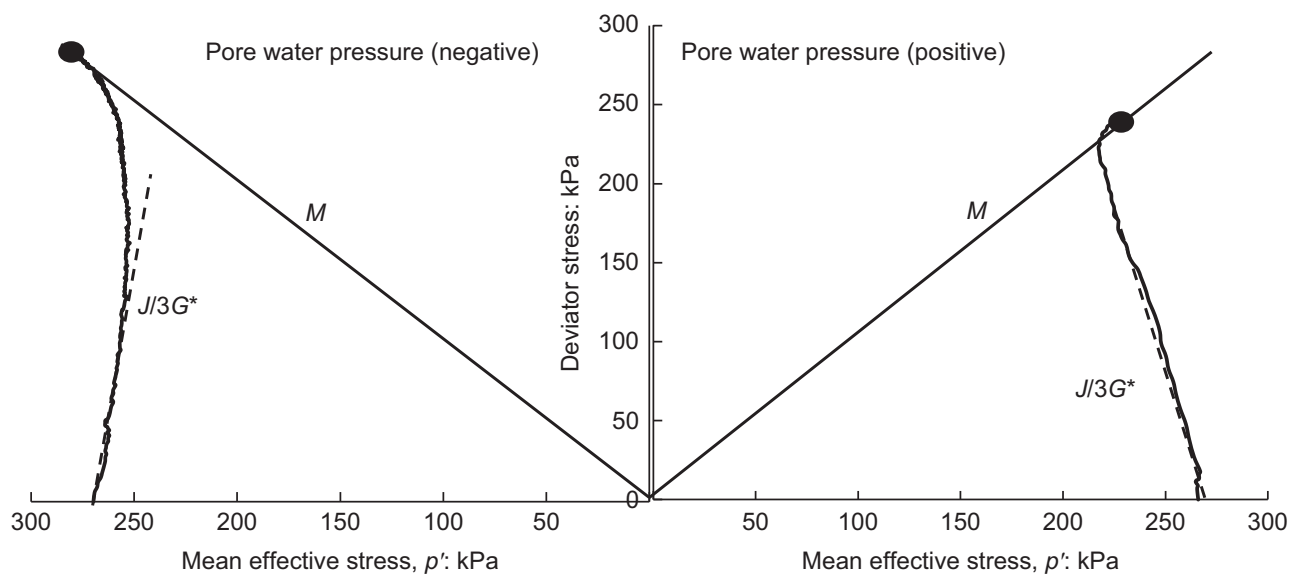

Fig. 9. Stress paths of Belfast clay loaded under undrained conditions (tests 14 and 15)

The $B$-value was examined on kaolin, Belfast and Oxford clays. The observations have shown that the $B$-value approximated to 1 from the very beginning of the application of confining pressure in a ramped fashion under undrained conditions. This has highlighted the possibility of avoiding the need for saturating samples by elevating back- and confining pressures. Further observations collected by shearing the samples to critical state confirmed that the $A$-values were not significantly affected by the pore water pressure being in the positive or negative range. The undrained stress paths obtained through two types of loading, as stated above, resulted in a similar trend, including capturing the degree of anisotropy. Stress relief is a significant issue in the sampling process. The investigation reported in this paper suggests that, although the sampling method is the primary cause of stress relief, other factors including particle size and clay minerology may contribute to further stress relief.

\section{NOTATION}

$A, B$ pore water pressure parameters

$A_{\mathrm{s}}$ revised pore water pressure ratio

$G^{*}$ modified shear modulus (Graham \& Houlsby, 1983)

$J$ coupling parameter

$M$ slope of critical state line

$p^{\prime}$ mean effective stress

$q$ deviator stress

$\Delta u \quad$ change in pore water pressure and

$\Delta \sigma_{1} \quad$ change in major principal stress

$\Delta \sigma_{3} \quad$ change in minor principal stress

\section{REFERENCES}

Baille, W., Tripathy, S. \& Schanz, T. (2014). Effective stress in clays of various mineralogy. Vadose Zone J. 13, No. 5: vzj2013.06.0112.

BSI (1990). BS 1377-Part 8: Methods of test for soils for civil engineering purposes. London, UK: BSI.

BSI (2018). BS EN ISO 17892-9: Geotechnical investigation and testing. Laboratory testing of soil. Consolidated triaxial compression tests on water saturated soils. London, UK: BSI.

Carrubba, P. (2000). Stress relief disturbance and residual pore pressure in cohesive soils. Soils Found. 40, No. 1, 57-72.

Clayton, C. R. I., Matthews, M. C. \& Simons, N. E. (1995). Site investigation: a handbook for engineers, 2nd edn. Cambridge, MA, USA: John Wiley \& Sons.

Delage, P., Menaceur, H., Tang, A. M. \& Talandier, J. (2016). Stress release and suction generation in the Callovo-Oxfordian claystone. ES3 Web of Conferences 9, article no. 18004.

Donohue, S. \& Long, M. (2009). Suction measurements as indicators of sample quality in soft clay. ASTM Geotech. Testing J. 32, No. 3, 286-297.
Donohue, S. \& Long, M. (2010). Assessment of sample quality in soft clay using shear wave velocity and suction measurements. Géotechnique 60, No. 11, 883-889, https://doi.org/10.1680/geot. 8.t.007.3741.

Doran, I. G., Sivakumar, V., Graham, J. \& Johnston, A. (2000). Estimation of in situ stresses using anisotropic elasticity and suction measurements. Géotechnique 50, No. 2, 189-196, https://doi.org/10.1680/geot.2000.50.2.189.

Graham, J. \& Houlsby, G. T. (1983). Anisotropic elasticity of a natural clay. Géotechnique 33, No. 2, 165-180, https://doi.org/ 10.1680/geot.1983.33.2.165.

Graham, J. \& Lau, S. L. K. (1988). Influence of stress-release disturbance, storage, and reconsolidation procedures on the shear behaviour of reconstituted underwater clay. Géotechnique 38, No. 2, 279-300, https://doi.org/10.1680/geot.1988.38.2.279.

Hight, D. W. \& Leroueil, S. (2003). Characterisation of soils for engineering purposes. In Characterisation and engineering properties of natural soils (eds T. S. Tan, K. K. Phoon, D. W. Hight and S. Leroueil), pp. 255-362. Lisse, the Netherlands: A. A. Balkema (Swets \& Zeitlinger).

Long, M. (2003). Characterization and engineering properties of Athlone laminated clay. In Characterisation and engineering properties of natural soils (eds T. S. Tan, K. K. Phoon, D. W. Hight and S. Leroueil), vol. 1, pp. 757-790. Lisse, the Netherlands: A. A. Balkema (Swets \& Zeitlinger).

Lourenço, S. D. N. (2008). Suction measurements and water retention in unsaturated soils. PhD thesis, Durham University, Durham, UK.

Lourenço, S. D. N., Gallipoli, D., Toll, D., Evans, F. \& Medero, G. (2007). Determination of the soil water retention curve with tensiometers. In Experimental unsaturated soil mechanics (ed. T. Schanz), pp. 95-102. Berlin, Germany: Springer-Verlag.

Lunne, T., Berre, T. \& Strandvik, S. (1997). Sample disturbance effects in soft low plastic Norwegian clay. In Recent developments in soil and pavement mechanics (ed. M. Almeida), pp. 81-102. Rotterdam, the Netherlands: Balkema.

Lynch, K., Sivakumar, V., Tripathy, S. \& Hughes, D. (2019). Development of a laboratory technique for obtaining soil water retention curves under external loading. Géotechnique 69, No. 4, 320-328, https://doi.org/10.1680/jgeot.17P.176.

Murray, E. J. (2002). Procedure for the determination of permeability of clayey soils in a triaxial cell using the accelerated permeability test, Technical Report p1-398/TR/2. Bristol, UK: Environment Agency.

Ridley, A. M., Dineen, K., Burland, J. B. \& Vaughan, P. R. (2003). Soil matrix suction: some examples of its measurement and application in geotechnical engineering. Géotechnique 53, No. 2, 241-253, https://doi.org/10.1680/geot.2003.53.2.241.

Sivakumar, V., Anderson, C., Solan, B., Rankin, B. \& Mackinnon, P. (2015). Influence of testing on permeability of compacted fine soils. Proc. Insth Civ. Engrs - Geotech. Engng 168, No. 5, 422-438.

Sivakumar, V., Navaneethan, T., Hughes, D. \& Gallagher, G. (2009). An assessment of the earth pressure coefficient in overconsolidated clays. Géotechnique 59, No. 10, 825-838, https://doi.org/10.1680/geot.8.P.033. 
Sivakumar, V., Donohue, D., Rodvand, L., Nanda, S. \& Tripathy, S. (2018). Behaviour of normally consolidated clay containing isolated solid inclusions. Proc. Instn Civ. Engrs - Geotech. Engng 171, No. 4, 345-356.

Skempton, A. W. (1954). The pore-pressure coefficients $A$ and $B$. Géotechnique 4, No. 4, 143-147, https://doi.org/10.1680/geot. 1954.4.4.143.

Skempton, A. W. \& Sowa, V. A. (1963). The behaviour of saturated clays during sampling and testing. Géotechnique 13, No. 4, 269-290, https://doi.org/10.1680/geot.1963.13.4.269.
Sridharan, A. \& Jayadeva, M. S. (1982). Double layer theory and compressibility of clays. Géotechnique 32, No. 2, 133-144, https://doi.org/10.1680/geot.1982.32.2.133.

Take, W. A. \& Bolton, M. D. (2003). Tensiometer saturation and the reliable measurement of soil suction. Géotechnique 53, No. 2, 159-172, https://doi.org/10.1680/geot.2003.53.2.159.

Young, A. G., Quiros, G. W. \& Ehlers, C. J. (1983). Effects of offshore sampling and testing on undrained soil shear strength. Proceedings of the 15th annual offshore technology conference, Houston, TX, USA, pp. 193-204. 